\title{
The Toxic Effect of Oxygen Upon the Aerosol Survival of Escherichia coli B
}

\author{
By C. S. COX AND F. BALDWIN \\ Microbiological Research Establishment, Porton, Salisbury, Wiltshire
}

(Accepted for publication I9 April 1967)

SUMM AR Y

At high relative humidity (RH) similar survivals were obtained for storage in oxygen, air or nitrogen. At low RH the survival in nitrogen was much greater than that in air or in a $20 \%(\mathrm{v} / \mathrm{v})$ oxygen $+80 \%(\mathrm{v} / \mathrm{v})$ nitrogen mixture, in which the survivals were similar. In oxygen alone, survival was even lower than in air. Hence oxygen, or a trace contaminant in it, was responsible for the poorer survival in air than in nitrogen. The mechanism of death caused by oxygen is discussed.

\section{INTRODUCTION}

The aerosol survival of Escherichia coli has been shown by Cox (1966a, $b ; 1967)$ to depend upon several variables. Amongst these was the nature of the atmosphere, in that at low relative humidity $(\mathrm{RH})$, but not at high $\mathrm{RH}$, survival was much greater in nitrogen than in air (Cox, 1966a; Cox \& Baldwin, 1966). The previous suggestion that this survival difference was owing to the toxic action of oxygen (Cox, 1966a) is now examined. Hess (1965) found that at low RH, but not at high, oxygen caused enhanced death of aerosolized Serratia marcescens and Escherichia coli $\mathbf{B}$.

\section{METHODS}

The methods used were as previously reported (Cox, 1966a) except that in all experiments a rotating drum container (Goldberg, Watkins, Boerk \& Chatigny, I958) was used for storing the aerosol cloud, and only Escherichia coli B sprayed from distilled water was studied. The drum apparatus used for the present work was similar to that used by Cox (1966a).

\section{RESULTS}

Results are given in Table I and show that at high RH similar survivals were obtained for storage in oxygen $(>99.5 \%)$, air or nitrogen $(>99.9 \%)$. At low RH the survival in nitrogen was much greater than in air or in a $20 \%(\mathrm{v} / \mathrm{v})$ oxygen $+80 \%(\mathrm{v} / \mathrm{v})$ nitrogen mixture, in which the survivals were similar. In oxygen alone survival was even lower than in air. Hence oxygen, or possibly a trace contaminant in it, was responsible for the poorer survival in air than in nitrogen. Analytical data of the oxygen did not suggest any obvious contaminants that were likely to have a toxic action at the parts per million concentrations at which they were present. However, such possibilities are not excluded completely since oxidizing agents such as ozone and the oxides of nitrogen at concentrations of a few parts per million might be toxic for Escherichia coli B in aerosols at low RH values. Also, oxygen + other 
oxidizing agents might have a marked synergistic effect. It is possible therefore that survival in air might be greatly affected by its composition, which might vary appreciably from place to place.

Table I. The aerosol survival of Escherichia coli $\mathrm{B}$ sprayed from distilled water into different gas phases

\begin{tabular}{|c|c|c|c|c|c|}
\hline & & \multicolumn{4}{|c|}{ Aerosol storage time (min.) } \\
\hline & & 0 & 15 & 30 & 60 \\
\hline $\mathrm{RH}^{*}$ & & \multicolumn{4}{|c|}{ Survival (\%) } \\
\hline 90 & Oxygen & 100 & 27 & II & 8 \\
\hline 90 & Air & 100 & 22 & 12 & 8 \\
\hline 90 & Nitrogen & 100 & 20 & I4 & I I \\
\hline 40 & Oxygen & 100 & 7 & 2 & I \\
\hline 40 & Air & 100 & 40 & 24 & I4 \\
\hline 40 & $\begin{array}{l}80 \%(v / v) \text { Nitrogen } \\
+20 \%(v / v) \text { oxygen }\end{array}$ & 100 & 32 & 16 & II \\
\hline 40 & Nitrogen & 100 & 90 & 85 & 80 \\
\hline
\end{tabular}

The results presented here and in the papers of Cox (I966a), Cox \& Baldwin (I966) and Anderson (1966) for the aerosol survival of Escherichia coli B in air at low RH show discrepancies in the degree of survival. These occurred even though similar methods of growth, aerosol generation, storage, collection and assay were used. In nitrogen, similar survival values were obtained; the $30 \mathrm{~min}$. survival of $85 \%$ (Table $\mathrm{I}$ ) compared favourably with that of $84 \%$ reported by Cox (1966a). These comparisons suggest that other factors operate to modify the toxic action of oxygen. One of these factors might be the exact composition of the air used.

Oxygen toxicity is not confined to Escherichia coli and Serratia marcescens in aerosols, since freeze-dried $E$. coli is also susceptible to oxygen poisoning (Lion \& Bergmann, 196 I $a, b$; Lion, I963) as is $S$. marcescens (Bateman, McCaffrey, O'Connor \& Monk, I96I ; Benedict et al. 196I ; Dewald, I966a,b). To consider the mechanism of death caused by oxygen the following observations are relevant. Experiments in conjunction with Dr B. B. Singh (Royal Military College of Science, Shrivenham) using electron spin resonance showed that a free-radical reaction mechanism was involved for $E$. coli в in the freeze-dried state in air. Under similar conditions free radicals were detected by Dimmick, Heckley \& Hollis (I96I) and by Lion, Kirby-Smith \& Randolph (196I). Such a mechanism may also occur for bacteria in the aerosol. Benbough (1967) suggested that the action of oxygen on $E$. coli $\mathrm{B}$ in the aerosol and in the freeze-dried state caused damage to flavin-linked enzymes. Free radicals may be involved, since metabolic inhibitors and free-radical scavengers protected $E$. coli B sprayed from distilled water into air at low RH (Benbough, I967). It is perhaps surprising that $E$. coli $\mathrm{B}$ which suffered this damage and also suffered a temporary and severe loss of ability to synthesize $\beta$-galactosidase (Anderson, I966) as well as a loss of control of potassium ions (Anderson \& Dark, 1967 ) was able to reproduce phage $T 7$ to a marked extent (Cox \& Baldwin, 1964, 1966; Webb, Dumasia \& Singh Bhorjee, 1965). This production of phage was very much greater than the ability of the bacteria to 
form colonies. Since DNA, RNA and protein synthesis are required for phage production these processes must occur in $E$. coli B killed by oxygen. Therefore the damage reported by Anderson (1966), Benbough (1967) and Anderson \& Dark (1967) may not have been directly implicated in the inability of $E$. coli B to replicate when aerosolized from distilled water and recovered from air at low RH. As mentioned previously in this paper, more than one death mechanism operates for $E$. coli in the aerosol. That caused by oxygen operated differently to the other death mechanisms which occurred at high RH, as shown by Cox (1966 a, $b ; 1967)$ and by Cox \& Baldwin (1966); Benbough's (1967) results supported these findings. These other death mechanisms, independent of the presence of oxygen, are not discussed here; they are reviewed by Anderson \& Cox (1967).

The authors thank Mr I. H. Silver for his interest in this work and Mr M. J. Perry for technical assistance.

\section{REFERENCES}

ANDERSON, J. D. (I966). Biochemical studies of lethal processes in aerosols of Escherichia coli. J. gen. Microbiol. 45, 303 .

Anderson, J. D. \& Cox, C. S. (1967). Microbial survival. Symp. Soc. gen. Microbiol. r7, 203.

ANDERson, J. D. \& DARK, F. A. (I967). Studies on the effects of aerosolization on the rates of efflux of ions from Escherichia coli strain B. J. gen. Microbiol. 46, 95.

Bateman, J. B., McCaffrey, P. A., O'Connor, R. J. \& Monk, G. W. (1961). Relative humidity and the killing of bacteria. The survival of damp Serratia marcescens in air. Appl. Microbiol. 9, 567.

BeNBovGH, J.E. (1967). Death mechanisms in airborne Escherichia coli. J. gen. Microbiol. 47, 325.

Benedict, R. G., Sharpe, E. S., Corman, J., Meyers, G. B., Baer, E. F., Hall, H. H. \& JaCkson, R. W. (196I). Preservation of microorganisms by freeze-drying. II. The destructive action of oxygen. Additional stabilizers for Serratia marcescens. Experiments with other organisms. Appl. Microbiol. 9, 256.

Cox, C. S. (1966a). The survival of Escherichia coli atomized into air and into nitrogen from distilled water and from solutions of protecting agents, as a function of relative humidity.J. gen. Microbiol. 43, 383 .

Cox, C. S. (1966b). The survival of Escherichia coli in nitrogen under changing conditions of relative humidity. J. gen. Microbiol. $45,283$.

Cox, C. S. (1967). The aerosol survival of Escherichia coli JEPP sprayed from protecting agents into nitrogen atmospheres under shifting conditions of relative humidity. J. gen. Microbiol. 49, I09.

Cox, C. S. \& BALDWIN, F. (1964). A method for investigating the cause of death of airborne bacteria. Nature, Lond. 202, 1135.

Cox, C. S. \& BALDwIN, F. (1966). The use of phage to study causes of loss of viability of Escherichia coli in aerosols. J. gen. Microbiol. 44, 15.

Dewald, R. R. (I966a). Preservation of Serratia marcescens by high vacuum lyophilization. Appl. Microbiol. $\mathbf{1 4}, 561$.

DewaLd, R. R. (I966b). Kinetic studies on the destructive action of oxygen on lyophilized Serratia marcescens. Appl. Microbiol. 14, 568.

Dimmick, R. L., Heckley, R. S. \& Hollis, D. P. (I96I). Free-radicle formation during storage of freeze-dried Serratia marcescens. Nature, Lond. 192, 776.

Goldberg, L. J., Watxins, H. M. S., Boerke, E. E. \& Chatigny, M. A. (1958). The use of a rotating drum for the study of aerosols over extended periods of time. Am. J. Hyg. 68, 85 .

Hess, G. E. (1965). Effects of oxygen on aerosolized Serratia marcescens. Appl. Microbiol. 13, 781.

LION, M. B. (1963). Quantitative aspects of the protection of freeze-dried Escherichia coli against the toxic effect of oxygen. J. gen. Microbiol. 32, 321.

LION, M. B. \& BERGMANN, E. D. (I96I $a$ ). The effect of oxygen on freeze-dried Escherichia coli. J. gen. Microbiol. 24, I9I.

LiON, M. B. \& BRRGMANN, E. D. (1961 b). Substances which protect lyophilized Escherichia coli against the lethal effect of oxygen. J. gen. Microbiol. 25, $29 \mathrm{I}$.

LION, M. B., KIRBY-SMTH, J. S. \& RANDOLPH, M. L. (I96r). Electron spin resonance signals from lyophilized cells exposed to oxygen. Nature, Lond. 192, 34.

Webi, S. J., Dumasia, M. D. \& Singh BhorJee, J. (1965). Bound water, inositol and the biosynthesis of temperate and virulent bacteriophages by air-dried Escherichia coli. Can.J. Microbiol. 11, 141. 